\title{
Onemocnění covid-19 v domově sociálních služeb pohledem zaměstnanců Josef Nota
}

DOI: $10.32725 /$ cetv.2021.016

\begin{abstract}
Abstrakt:
Zkoumanou problematikou je dopad nákazy novým typem koronaviru v prostředí domova sociálních služeb; důležitost problematiky je možné spatřovat v tom, že se téma bezprostředně týká životů všech aktérů, kteří jsou spjati s prostředím sociálních služeb. Účelem bylo za pomoci príběhů získaných od pomáhajících pracovníků nahlédnout na subjektivní obraz, který znázorňuje, do jaké situace se aktéři nástupem pandemie a zavedením protipandemických opatření v současnosti dostávají a jak čelí (do této doby) neznámé výzvě. Snahou tohoto příspěvku bylo za použití kvalitativních výzkumných nástrojů zachytit autentické výpovědi respondentů v konkrétním prostředí a pokusit se vyhnout účelovým interpretacím, ke kterým téma může svádět. Kromě ilustrace př́běhů respondentek studie představuje také sedm stěžejních témat vzniklých po sběru dat a následném kódování, argumentace je závislá na postoji zpovídaných respondentů. Závěry z kvalitativní studie nabízejí výchozí bod pro pochopení aktuální vážné situace, dávají možnost porozumět zkoumanému jevu v komplexnější podobě autentických výpovědí a mohou být použity pro potřeby výzkumů, které se zabývají možnými dopady koronakrize na zúčastněné aktéry v prostředí domovů sociálních služeb.
\end{abstract}

Klíčová slova: covid-19, zaměstnanci, domov sociálních služeb, sociální služby, pomáhající profese, senior, protipandemická opatření, kvalitativní výzkum

\section{Výzkumný problém a výzkumná otázka}

Mezi nejrizikovější pracoviště v souvislosti se šířením koronavirové nákazy patří mimo jiné i zařízení poskytující svým klientům sociální služby. Problémem není pouze snadné komunitní šíření onemocnění. Tato zařízení zároveň pečují o skupinu klientů, kteří jsou případnou nákazou novým typem viru bezprostředně ohroženi na životě $\mathrm{z}$ důvodu větší náchylnosti k horšímu průběhu onemocnění covid-19. ${ }^{1}$

Námi zkoumaný domov sociálních služeb² je zařízení, které patrně patřilo mezi nejvíce postižené

1 Srov. (C) Covid portál, Návštěvy sociálních zařízení. Pravidla a doporučení (on-line), dostupné na: https://covid.gov.cz/situace/ nemocnice-socialni-zarizeni/navstevy-socialnich-zarizeni, aktualizace dne 07. 12. 2020, citováno dne 05. 02. 2021.

2 Dále jen DSS, poprípadě „domov“. 
koronavirem v rámci celého kraje. ${ }^{3}$

Cílem tohoto článku je proto porozumět, JAK tuto nelehkou situaci vnímají a prožívají pracovnice vybraného DSS a PROČ právě takovým způsobem. Optika výzkumu byla přenesena na subjekty výzkumného problému (v tomto př́padě na vychovatelky domova).

Zformulovaná hlavní výzkumná otázka zní: Jak prožívají aktuální situace vzniklé ve spojení s epidemií covid-19 domovy sociálních služeb?

\section{Design a metoda výzkumu}

S ohledem na zformulovanou výzkumnou otázku byl zvolen kvalitativní př́stup ke zkoumanému jevu, nebot’ v položené otázce jde o rozkrytí některých ne zcela jasných jevů. ${ }^{4}$

Informantkami jsou dvě konkrétní zaměstnankyně DSS pracující na pozici „aktivizační pracovník v sociálních službách“, zároveň jsou také studentkami programu pedagogika volného času na TF JU.

Základnou dat byla skutečnost, že informantky psaly v průběhu jednoho semestru eseje otevřeného tvaru, ${ }^{5}$ přičemž jádro sdělení těchto esejů se stalo základem pro hloubkový, nestrukturovaný rozhovor. Ten se odvíjel od základní výzkumné otázky. Forma doplňujících otázek není pro design výzkumu významná, nebot doplňující otázky byly kladené s cílem získat hlubší porozumění danému sdělení a odvíjely se spontánně a přirozeně na základě vyprávění informantek. Data $\mathrm{z}$ rozhovorů byla nahrávána, poté doslovně přepsána a následně analyzována. Záměrem analýzy bylo zpracovat data smysluplným způsobem a nalézt odpověd’ na položenou otázku. Pro analýzu bylo zvolené otevřené kódování. Vzniklé kódy byly poté seskupeny (kategorizovány) do pojmů, které př́slušely stejnému jevu, a následně interpretovány s cílem porozumět fenoménům, které vyvstaly v průběhu procesu.

\section{Data z výzkumu a etika šetření}

Základnou dat jsou autorské eseje, které sloužily $\mathrm{k}$ formulaci základní výzkumné otázky, a především hloubkové, nestrukturované rozhovory realizované s cílem najít odpověd’ na výzkumnou otázku. ${ }^{6}$ Jména informantek byla z etických důvodů anonymizována, zmíněné pracoviště je jmenováno a představeno pouze obecně. Informantky souhlasily s výzkumem a konečná podoba článku jim byla poskytnuta ke schválení.

\section{Otázky kvality a interpretace výzkumu}

Prvotním impulsem pro formulaci základní výzkumné otázky a výzkumu vůbec byla sdělení získaná z autorských esejů dvou informantek. Po analýze sdělení z esejů byla zformulována základní výzkumná otázka a s informantkami byly realizovány nestrukturované rozhovory.

Triangulace byla použita nikoliv v kontextu snah o posílení validity sebraných dat (postavením dvou rozdílných metod proti sobě), ale ve druhém pojetí, tedy jako strategie vedoucí k podpoře poznatků pomocí získávání dalších informací. Data z esejů a hloubkových rozhovorů proto ne-

Název kraje není uváděn záměrně z etických důvodů.

Srov. Roman ŠVAŘíČEK, Klára ŠEĎOVÁ, Kvalitativní výzkum v pedagogických vědách: Pravidla hry, Praha: Portál, 2007.

Praxe ukázala, že pro účely kvalitativního zkoumání je výhodnější, když studenti opakovaně prochází zkušeností, že jejich autorské úvahy zadané v rámci kurzů konkrétního studijního programu nejsou hodnoceny z hlediska formy a obsahu. Pouze odevzdal/neodevzdal.

7 Srov. Michal MIOVSKÝ, Kvalitativní prístup a metody v psychologickém výzkumu, Praha: Grada, 2006. 
jsou uměle izolována, konečné sdělení představené čtenáři je tvarem, který vznikl syntézou všech získaných dat.

Záměrem bylo, aby interpretace dat nesměřovala $\mathrm{k}$ podpoře předem daných názorů výzkumníka a aby se předešlo známému jevu kvalitativních studií zvanému „nadinterpretace“ (ambice nacházet v datech něco, co v nich ve skutečnosti není, a promítat do nich tak své implicitní teorie); sdělení směřující k zodpovězení výzkumné otázky má těžiště ve výpovědích informantek, jak je v kvalitativním výzkumu žádoucí. ${ }^{8}$

Limitem výzkumu je získání dat pouze od dvou informantek. S ohledem na množství získaných dat byla nutná redukce.

Osobní data informantek jsou uváděna záměrně: věŕíme, že bližší charakteristika informantek pomáhá $\mathrm{v}$ pochopení kontextové logiky kvalitativního šetření.

\section{Teoretická východiska k problému}

Fenomén je zkoumán v prostředí sociálních služeb. Zjednodušená definice sociální práce by zněla takto: jde o specificky zaměřenou činnost orientovanou na pomoc lidem v nestandardní a obtížné životní situaci. ${ }^{9} \mathrm{~V}$ odborných publikacích je tato profese běžně spojována se zrcadlením ideálů společnosti. ${ }^{10}$ Pomáhající profese můžeme vymezit poměrně jednoduchou charakteristikou, a to tak, že se vyznačují prací s lidmi. Jedná se o celou škálu profesí, at už zdravotnického, pedagogického nebo právě sociálního charakteru. ${ }^{11} \mathrm{~V}$ rámci pomáhajících profesí hraje ústřední roli lidský vztah, čímž se pomáhající profese odlišují od jiných profesí, ve kterých figuruje sociální interakce. ${ }^{12} \mathrm{~V}$ širší rovině se zde uvažuje o lidském vztahu jako o základním „nástroji“ při výkonu tohoto povolání. ${ }^{13}$

Sociální služby jsou profesionalizovány: cílem je př́prava kvalifikovaných sociálních pracovníků, jejichž odbornost je deklarována tím, že jsou schopni aplikovat do praxe znalosti z různých oborů (sociologie, psychologie) a jsou kompetentní k práci s konkrétním člověkem. ${ }^{14}$

Sociální služby mohou být pobytové, ambulantní či terénní. DSS se orientuje zpravidla na poskytování pobytových služeb se zajištěním stravy a zdravotní a sociální péče. DSS se různým způsobem klasifikují.

Mezi nejpočetnější skupiny př́ijemců sociálních služeb patří zejména senioři, lidé se zdravotním postižením, rodiny s dětmi, ale také lidé, kteří z různých důvodů žijí „na okraji“ společnosti. ${ }^{15}$ Uživatelům DSS jsou poskytovány, dle zákona č. 108/2006 Sb., tyto služby: poskytnutí stravy; poskytnutí ubytování; pomoc při osobní hygieně nebo poskytnutí podmínek pro osobní hygienu; pomoc při zvládání běžných úkonů péče o vlastní osobu; sociálně terapeutické činnosti; výchovné, vzdělávací a aktivizační činnosti; zprostředkování kontaktu se společenským prostředím; pomoc při uplatňování práv, oprávněných zájmů a při obstarávání osobních záležitostí $V$ domovech, kde jsou uživateli i děti a mládež, má být poskytováno vzdělávání a výchova. Dospělým uživatelům domova je zase (s přihlédnutím $\mathrm{k}$ jejich možnostem) poskytováno pracovní uplatnění. ${ }^{16}$

\footnotetext{
Srov. tamtéž, s. 203

Srov. Stibor HATÁR, Sociálna pedagogika, sociálna andragogika a sociálna práca - teoretické, profesijné a vztahové reflexie, Praha: Česká andragogická společnost, 2009, s. 75.

10 Srov. Zuzana HAVRDOVÁ, Kompetence v praxi sociální práce, Praha: Osmium, 1999, s. 9.

11 Srov. Jiř́ JANKOVSKÝ, Etika pro pomáhající profese, Praha: Triton, 2018, s. 9.

12 Srov. Karel KOPŘIVA, Lidský vztah jako součást profese, Praha: Portál, 2013, s. 25-26.

13 Srov. tamtéž, s. 14-15.

14 Srov. Igor TOMEŠ, Sociální politika, sociální služby a sociální práce, in: Základy sociální práce, ed. Oldřich MATOUŠEK, Praha: Portál, s. $179-180$.

15 Srov. Jan MICHALÍK, Smluvní vztahy v sociálních službách, Olomouc: VCIZP, 2008.

16 Srov. Iva ŠVARCOVÁ, Mentální retardace, Praha: Portál, 2006.
} 
Mimořádná situace spojená s pandemií covidu-19 v době psaní tohoto článku tematicky rychle plní stránky odborných zahraničních i tuzemských časopisů. Problematika dopadu pandemie covidu-19 je ve studiích a vysokoškolských závěrečných pracích často mapována s použitím nástrojů ekonomických věd. ${ }^{17}$

Dominují především anketní výzkumy (těžištěm jsou strukturované otázky), které byly realizovány za účelem prvotního zhodnocení situace a k reflexi dopadu epidemie na sociální služby, ${ }^{18}$ zmínit můžeme i anketní výzkum Institutu sociální práce realizovaný ve spolupráci s agenturou NMS Market Research (respondenti odpovídali na několik uzavřených a jednu otevřenou otázku). ${ }^{19}$ Tématu se dotýká např. „Mezinárodní výzva proti ohrožení, vyloučení a věkové diskriminaci starších lidí během pandemie covidu-19“ (tzv. Galwayská výzva), která obsahuje čtyři sdělení: „(1) Reakce státu a společnosti na covid-19 musí brát v potaz přímá vyloučení, která postihují starší občany $\mathrm{v}$ důsledku politik a strategií zaváděných $\mathrm{v}$ rámci boje proti viru, a tam, kde je to možné, kompenzovat negativní okolnosti podporou a aktivitou.“ (2) „Je třeba dbát na to, aby se ošetření pacientů, kteří jsou nakaženi covidem-19, i další formy alokace zdrojů spojených s krizí prováděly na základě potřebnosti, nikoliv prosté věkové hranice.“ (3) „Při zavádění politik a strategií $\mathrm{k}$ ochraně starších lidí během pandemie nesmíme zpochybnit heterogenitu starší populace a zaškatulkovat starší občany jen jako vysoce zranitelné a pasivní jedince a ignorovat tak jejich přínos v úsilí vzdorovat pandemii.“ (4) „Politiky a strategie zaměřené na boj s covidem-19 nesmí být v kontextu krize založeny na problematizování stárnutí a starších lidí, ani destabilizovat výraznou solidaritu mezi generacemi, jíž jsme v současnosti svědky. “20

Jádrem pro diskuzi nad výsledky našeho výzkumu bude také zpráva pracovní skupiny Rady vlády pro duševní zdraví, která iniciovala šetření v oblasti dopadu krize způsobené covidem-19 na duševní zdraví populace ČR. ${ }^{21}$

Z realizovaných kvalitativních šetření můžeme zmínit závěrečnou práci Holmajerové zaměřenou na životní zkušenosti seniorů žijících ve vlastní domácnosti, kteří mají omezený kontakt s druhými z důvodu protipandemických opatření. Na základě kvalitativního šetření kategorizovala pět hlavních témat, kterými se snažila zodpovědět výzkumnou otázku („život jde dál, ale co se s tim nadělá, na něco umřít musim“; stabilita přetrvávající v životě seniora navzdory nestabilní situaci; udržení soudržnosti s blízkými obranou proti pocitu sociální izolace; subjektivní vnímání okolí se najednou stává negativnějším a opatření pomáhají i škodí). Tato závěrečná práce ale nepostihuje plně problematiku, na kterou je zaměřen tento př́spěvek, nebơ zkoumá informantky z odlišného prostředí (vlastní domácnost / DSS), navíc referuje o postojích zdravých žen ve věku nad 65, které neměly reálnou životní zkušenost s koronavirovou nákazou. ${ }^{22}$

17 Srov. Alexandra BOYARKINA, Analysis of the Economic Impact of COVID-19 on the Hospitality Industry in the Czech Republic (on-line), dostupné na: https://theses.cz/id/ssqe7r/, citováno dne 16. 04. 2021; Michal HAMPEJS, Dopad COVID-19 na lidský kapitál (on-line), dostupné na: https://theses.cz/id/rbf9l0/, citováno dne 18. 04. 2021.

18 Srov. Pavel KLIMENT, Lenka NÁDVORNÍKOVÁ, Prvotní reflexe dopadu pandemie koronaviru na sociální služby v ČR, Fórum sociální práce 2/2020, s. 20-28.

19 Srov. @ Stručná interpretace výsledků výzkumu Institutu sociální práce realizovaného ve spolupráci s agenturou NMS Market Research (on-line), dostupné na https://zitdoma.cz/wp-content/uploads/sites/2/2020/09/TZ_ISP_Interpretace_vysledku.pdf, citováno dne 19. 04. 2021.

20 Překlad $z$ angličtiny, viz (c) Combatting exclusions and ageism for older people during the COVID-19 Pandemic: Four Key Messages (on-line), dostupné na: http://rosenetcost.com/combatting-exclusions-and-ageism-for-older-people-during-the-covid-19-pandemic/, citováno dne 18. 04. 2021.

21 Srov. ( Dopady krize způsobené koronavirem SARS-CoV-2 a duševního zdraví populace ČR - zpráva pracovní skupiny Rady vlády pro duševní zdraví (on-line), dostupné na: https://www.mzcr.cz/wp-content/uploads/2020/01/Dopady-krize-zp\%C5\%AFsoben\%C3\%A9koronavirem-SARS-CoV-2-a-du\%C5\%A1evn\%C3\%ADho-zdrav\%C3\%AD-populace-\%C4\%8CR.pdf., citováno dne 20. 04. 2021.

22 Srov. Eva HOLMAJEROVÁ, Životní zkušenost s omezeným kontaktem seniorů ve vlastní domácnosti a jejich prožívání protiepidemických opatření (on-line), dostupné na: https://is.muni.cz/th/nqk1a/, citováno dne 20. 04.2021. 


\section{Představení konkrétního DSS}

Zmíněný domov poskytuje služby klientům, kteří mají s ohledem na věk či zdravotní postižení sníženou soběstačnost. Vyžadují proto pravidelnou pomoc od ostatních, včetně poskytnutí sociálních služeb (ubytování, stravování a péči v pobytovém zařízení). Domov přijímá mentálně i fyzicky postižené klienty od 27 let věku. Druhou, velmi početnou skupinou jsou senioři. Ve druhé vlně epidemie v domově onemocněla naprostá většina klientů a také téměř polovina personálu. ${ }^{23}$

Pro porozumění situace v tomto konkrétním domově nám pomohou výpovědi dvou informantek, které jsou sice kolegyněmi ve zmíněném domově, ale každá pracuje s jinou skupinou klientů domova a na jiném oddělení. Jejich odlišná profesní zkušenost proto nabízí možnost vidět zkoumaný jev komplexněji.

\section{Př́běh informantky 1}

Informantka 1 vystudovala střední pedagogickou školu. Je matkou dvou dětí, ve školství pracuje osmým rokem.

Pět let měla informantka 1 podanou žádost o pracovní místo ve zmiňovaném DSS, než získala pozici jako „aktivizační pracovník v sociálních službách“ v oddělení seniorů.

Její pracovní náplní je rozvíjení jemné motoriky a manuální zručnosti klientů. Organizuje volnočasové aktivity, podílí se na jejich realizaci a zabezpečuje pro klienty kulturní a zájmové činnosti. Individuálně se věnuje klientům, kteří potřebují psychickou pomoc. Ve své autorské eseji na konci ledna zformulovala př́iběh, který se stal námětem pro další, nestrukturovaný rozhovor a narativní interview. Všechna data ve zhuštěné, redukované podobě ilustrují úsek př́běhu zaznamenávající rozšíření nákazy v DSS:

Informantka 1: První signály, že není vše v pořádku, přišly hned po víkendových volbách 2020 z kuchyně „domova“. V kuchyni pomáhají také někteři mentálně postižení klienti a ti bohužel roznesli nákazu (kterou získali od jednéz kuchařek), po celém zařizení. Kolegyně, která se mnou pracuje jako aktivizační pracovnice, byla pozitivně testována a já myslela, že jsem také „jasná“. Měla jsem šilené bolesti hlavy a zad. Ale negativní test mě presvědčil o opaku, nakonec jsem měla jen zablokovanou krční páteř, prý ze stresu. Musela jsem nosit chvíli krční límec a moc se nehýbat. O to horší pro mne bylo zůstat doma a sledovat vše jen zpovzdálí. Nákaza se postupně rozšírila do celého domova. Za tři týdny nám zemřelo sedmnáct klientů. Vètšinu jsem oplakala. Je pravda, že je to jen práce, ale pracuji zde čtyři roky a většinu klientů mám jako svou rodinu. Už neuvidím (jméno), mentálně na úrovni pětiletého ditěte, jak na mně pokřikuje kafe! Kafe! Ani paní (jméno), která byla úžasná, vtipná, milá dáma. A další. Jak je člověk bezmocný a svirá ho zoufalství, že nemůže pomoci. A další den odejde znovu člověk...

Vím o nich hodně. Jaký měli život, jaké trápení s dětmi, jaké nemoci, jaký byl partner... Nemusela jsem chodit $k$ li̊žku v ochranném obleku, ve kterém se člověk nepředstavitelně potí. Nemusela jsem jim pomáhat při horečkách a při průjmech, jako kolegyně od lůžek. Nemusela jsem být př́mo u umírání našich klientů, většina zemřela prímo v domově. Ale to zoufalství při zbytečné smrti u lidí je hrozné i tak. Byly mezi nimi lidé, kterým nebylo ještě ani sedmdesát let, měli jen vysoký tlak nebo cukrovku. A jinak byli zcela v pořádku.

Po třech týdnech jsem se vrátila do práce a snažila všem klientkám zpř́ijemnit den. Pomalu jsme

23 S ohledem na povahu citlivých dat, se kterými je zde zacházeno, je nutné představit tento DSS pouze obecně. 
rozjižděli aktivity, bavili se u písniček a snažili se zapomenout, že vlastně nemůžeme vůbec nikam. Většina klientek velmi špatně snáší, že za nimi nemưže rodina. A Skype jim moc neříká. Jestli je vám devadesát, tak to že dceru uvidíte na půl hodiny na obrazovce, nemůžete se jí dotknout a zasmát se s ní, vás moc nenadchne. Vètšina klientek potřebuje dotek. Při skypování mě většinou drží za ruku a nechtějí mě ani poté pustit.

Bohužel po týdnu a půl v zaměstnání jsem se i pres používání ochranných pomůcek nakazila covidem i já. Měla jsem naštěstí jen lehčí formu: s horečkou, bolestmi svalů a bolestí hlavy. Byla jsem doma čtrnáct dní a zítra znovu nastupuji k mým klientům. (...).

\section{Př́běh informantky 2}

Informantka 2 vystudovala maturitní obor s názvem Rodinná škola - ekonomicko- administrativní služby. Po maturitě navštěvovala jazykovou školu se zaměřením na německý jazyk. Studium na Pedagogické fakultě, studijní program německý jazyk se zaměřením na vzdělávání nedokončila $z$ rodinných důvodů. Je vdaná, $s$ manželem vychovává dvě děti.

Po přečtení všech esejů informantky 2 a po realizaci nestrukturovaného rozhovoru jsem informantce položil ještě několik doplňujících otázek, které vznikly dodatečně při přepisování rozhovorů. Informantka 2 napsala další z autorských esejů, velmi autentický, otevřený, ze kterého zde uvádím jen některé osobní údaje.

Ve svém př́běhu popsala, že odmalička vlastně žila ve společnosti seniora (starala se kromě dalších členů rodiny i o dědečka). Ve chvíli, kdy se dědečkův zdravotní stav zhoršil a informantka mu nebyla schopna dopřát veškerou potřebnou péči, byl přijat do domova poskytujícího sociální služby.

Do zmíněného DSS později - po narození prvního dítěte - nastoupila na pozici „aktivizačního pracovníka v sociálních službách“ na oddělení seniorů (tedy na pozici, kde nyní pracuje zmíněná kolegyně informantka 1 ).

Informantka 2 pracovala na oddělení seniorů rok a půl, náplní její práce byly aktivizační terapie, např. keramická a výtvarná dílna, četba se seniory, tanec vsedě a především hudební, aktivizační činnosti.

Po odchodu jedné kolegyně z oddělení tzv. „mladších klientư (30-60 let, klienti se zdravotním a mentálním postižením) přešla na její pozici. Na oddělení klientů se zdravotním a mentálním postižením pracuje jako aktivizační pracovník dodnes.

Informantka 2 situaci s pandemií na svém pracovišti popsala v následující autorské eseji (informantka 2: „Tahle esej se psala sama. Nad ní člověk nemusel př́liš dlouho dumat, stačilo se vypsat z reálií, ze životní situace."). Př́iběh byl opět zkrácen a sdělení redukováno pro účely výzkumné otázky.

Informantka 2: Bylo po víkendu a moji spolupracovníci se jeden po druhém nahlašovali, že nastupují na nemocenskou, at už s podezřením na covid-19 či jiné onemocnění. Současně je v našem domově zákaz vycházení mimo areál a sonemocnèním covid-19 zůstává $v$ karanténě i obsluha kantýny, což je jediná možnost, kde si klienti mohou nakoupit. V tu chvíli začíná teprve pořádný frmol. Zưstávám na oddělení výchovy sama. Takže je na mě $3 x$ týdně dojet na nákup nezbytných potřeb (cigarety, potraviny, drogerie) pro uživatele. Do toho volají rodiny klientü, zda by se s nimi mohli spojit přres Skype. Což člověk nedokáže odeprít, protože již v první vlně jsme zpozorovali, že kontakt s rodinou je pro naše seniory velice důležitý (pro některé z nich bohužel poslední). A tak skáču mezi obchodem, 
skypováním, účtováním nákupů, dezinfikováním všeho možného, zvedáním telefonů atd. Musím přiznat, že tři dny jsem jela „na doraz" A v okamžiku, kdy jsem $z$ chodby slyšela větu „máme 6 pozitivních klientü “ jako by se svět zastavil. Pak už to byl jen boj o čas, uchránit co nejvíce lidí od nakažení.

Ke své rodině jsem se večer vracela vyčerpaná, hlavně psychicky a moje myšlenky byli stále u našich seniorư, zda se nákaza zastaví. Při této vyčerpanosti si vůbec nepřipouštím nějaké náznaky príznaků i u mě. A po hromadném testování jsem docela překvapena textem příchozí SMS s výsledky: „pac. MH, PCR POZITIVNI“. V tuto chvíli mě dochází, že nyní budu mít času dost a strávím několik dní ve společnosti mé rodiny. Na jednu stranu to beru jako znamení, že už bylo na čase zpomalit a být se svými blizkými, zahrát si třeba společenskou hru, dát si s manželem v klidu kávu a třeba se kouknout na učení. Stále jsou ale moje myšlenky u našich seniorů a zájem o dění $v$ domově.

$V$ neposlední ŕadě se u mě objevuje strach o zdraví, nikoli mé, ale o zdraví mého otce, který je po léčbě rakoviny a bydlí ve společném domě. Okamžitě mu zakazuji, aby naši domácnost navštěvoval, a současně vidím, jak je mu smutno, kdyžje zvyklý na každodenní kontakt s námi, a hlavně vnoučaty. A nyni nám to musi vynahradit pouze telefonni hovory z patra do prízemí a naopak. Zvláštnísituace, která nastala. Napjatě jsme čekali na výsledky testů zbytku mé rodiny. Pozitivní bohužel je i manžel a dcera. Díky bohu syn-astmatik, i otec po rakovině, jsou negativní. Tím je krize v naší rodině snad chvili zažehnána a mnè se poprvé po delší době ulevilo.

Stále jsem ovšem sledovala šiření nákazy $v$ ČR a televizní a rozhlasové reportáže z mého zamèstnání. $Z$ (číslo) klientů je (číslo) nakažených a $k$ tomu (číslo) zaměstnancủ z (číslo). To mě velice zasáhlo a uronila jsem i slzy. Vidèt takto veřejnè obec a misto, které každodennè navštěvujete, lidi, které máte rádi, byl velice silný prožitek. Hned jak se mi udělalo lépe, cítila jsem potřebu navrátit se zpèt do zaměstnání a být nápomocná tam, kde to zrovna bude potřeba. Strach $z$ návratu po dvou týdnech doma, byl obrovský. Hlavně z toho, že už nenajdu v domově některé klienty. Což bohužel bylo pravdou, a i nadále úmrtí stoupá nejen u nás $v$ domově, ale i v republice. (...).

Tyto dva př́běhy zachycené v písemné eseji sloužily jako autentický obraz ilustrující vzniklé situace v DSS. Následující kapitoly budou věnovány stěžejním tématům, která vznikla po sběru dat z hloubkových, nestrukturovaných rozhovorů na základě otevřeného kódování a kategorizování. Snahou bylo, aby doplňující komentáře $\mathrm{v}$ následujících kapitolách nebyly zjednodušujícími interpretacemi. Těžiště sdělení pro čtenáře mělo spočívat $\mathrm{v}$ citovaných, autentických výpovědích. ${ }^{24}$

\section{Protipandemická opatření a dopady izolace}

Z důvodu pandemie covidu-19 ředitel domova do odvolání zakázal návštěvy klientů a vycházky klientů mimo areál domova. V nestrukturovaném rozhovoru informantka 1 problematiku izolace zmiňovala jako naprosto zásadní:

Informantka 1: Naši klienti ztrácí chut’ do života, ale to i lidé běžní, kteři zde nemusí být zavření. Klienti a klientky se stávají rozhodně mnohem otrávenější a je to logické. Oni mohou jen do parku vedle ústavu (a zaplat'-bủh alespoň za tuto možnost, nebot jinak by byli zavřeni pouze v budově). Ty omezené možnosti pohybu jsou určitě depresivní. Domnívám se, že u některých klienti̊ s narušenou psychikou navíc musela psychiatrička prístoupit $k$ silnějši medikaci.

Informantka 1 zmiňuje, že právě na oddělení seniorủ, kde pracuje, klienti velmi těžce snášejí odloučení od príbuzných. 
Informantka 1: Ti, co byli zvyklý se s príbuznými pravidelně vídat, odloučení prožívají těžce. Před covidem-19 za nimi jezdili př́buzní pravidelně dvakrát, třikrát týdně, vnoučata se u nich stř́dala. Tito senioři izolaci od př́mého kontaktu s př́buznými nesou hodně těžce.

Informantka 2 pracující ve skupině klientů s mentálním postižením si rovněž všímá dopadi̊, které způsobilo zavření areálů domova.

Informantka 2: Určitě je to náročné pro klienty i jejich rodiny. Sice je chceme ochránit před zavlečením nákazy, ale je patrné, že jim opatření vübec nesvědčí. Například pán zvyklý dennè chodit několik kilometrů, najednou může chodit pouze po parku (i když po velkém). Stává se proto agresivním, napadá nás. Dřive se po snídani sebral, šel se procházet a byl poté v klidu. Když je v současnosti de facto zavřen a mi̊že se procházet pouze parkem, nesvědčí mu, že nemůže z areálu pryč.

Informantka 2 je ovšem toho názoru, že protipandemická opatření ovlivňují skupinu seniorů kvalitativně odlišněji než „její“ skupinu klientů s mentálním postižením.

Informantka 2: U klientůs mentálním postižením mám pocit, že jim opatření tak bolavá neprijdou. Zvláště jedinci, kteří v ústavní péči žijí odmalička, trpízřejmě jinými věcmi, než pandemickou situací $v$ Česku. Kdo ale skutečně prožívá tuto situaci úkorně, jsou senioři.

$V$ naší skupině se klienti s mentálním postižením samožrejmě ptají, kdy budou moci ven, ale že by to až bolestně ř řsili, to ne. Uvedu př́iklad: zeptají se, kdy budou moci ven, ale je jim jedno, co odpovíte. Velmi často ani nepočkají na mou odpověd. Tedy: z pohledu zaměstnance se situace díky pandemii změnila strašně. Z pohledu klienta s mentálním postižením se ale žrejmě situace dramaticky nezměnila.

Nejnáročnější bylo vysvětlit klientưm s mentálním postižením, co se děje, v jaké situaci jsme se ocitli. Oni pochopili, že nemohou opustit areál a nemohou do vsi, a proto se neustále ptali, kdy zákazy skončí. Což my jsme ale nevěděli, nedokážeme stále vyvíjející se situaci predikovat. A ptají se nás vlastnè stále.

Nejhorší tedy je, že jim nemáte co odpovědět. Ptají se: „Kdy budou návštěvy?“ „Kdy budou moci prijet príbuzní?"

Skupinu klientů s mentálním postižením ovšem nenapadají otázky typu: „Co jejich rodiny a blízcí? Zda neonemocněli touto nemocí?" To predevším vzhledem $k$ tomu, že převážná část těchto klientů nemá rodinu. První, co začali řešit, bylo, proč mají nosit roušky? Některým z nich, i svéprávným, byla docela potíz vysvětlit nutnost nosit roušky i v domově, aby nedošlo $k$ nákaze mezi klienty, kteř́ mohou mimo domov a naše nemohoucí seniory. Nicméně - až na pár výjimek se nám vysvětlení situace a přsvědčení těchto klientů podařilo.

\section{Distanční formy komunikace v domově sociálních služeb}

Při rozhovoru s informantkou 1 mě zajímalo, zda by se videohovory seniorů s př́ibuznými nemohly stát plnohodnotnou alternativou setkávání v době nuceného omezení kontaktních návštěv. Informantka 1 srovnávala první a druhou pandemickou vlnu v souvislosti s klesajícím zájmem o realizaci videohovorů.

Informantka 1: Pro nás ta druhá vlna je ohromně rozdílná. V první vlně se realizovalo množství hovorů po Skype, príbuzní se o seniory tímto způsobem zajímali. V této druhé vlně se nic neděje. Veškerá komunikace je úplně mrtvá. Tato druhá vlna se vleče a už trvá dlouho, není už ani snaha komunikovat právě prostřednictvím videohovorů. Je to zvláštní... Dříve jsme nosili notebooky kvưli skypeovým hovorům třeba třikrát za den. Ted' nic.

Informantka 1 se domnívá, že důvodů může být více. Zejména jde o dlouhou dobu trvání druhé 
vlny pandemie, dalším možným důvodem je podle ní samotné specifikum videohovorů, které seniorům nemusí vyhovovat.

Informantka 1: Jedním $z$ di̊vodů žrejmě je velmi dlouhé trvání druhé vlny pandemie. Ztrácí se rodinné vazby. Jak rodina za svými starými př́buznými nechodí, rodinná pouta se trhají. Sejde z očí, sejde $z$ mysli.

Další (a možná prozaičtějuší) $z$ dưvodì je, že většina starších klientů (kolem osmdesáti a samozřejmě i devadesáti let) mají s realizací videohovoru potíze. Mluví do obrazovky, ale priitom hledají př́buzné okolo svého liǔka. Velmi často senioři slovům z reproduktorů nerozumí, př́ibuzní se musí opakovaně ptát. Senioři se nemohou svých dètí dotknout, nemají je u sebe a chybí proto možnost, aby na ně fixovali svou pozornost. Na počítač totiž obvykle i špatně vidí. Tedy: i př́ibuzní mohou nabýt dojmu, že to skypování ztrácí smysl.

Informantka 1 je toho názoru, že videohovory nejsou sice plnohodnotnou náhradou za osobní kontakt, ale že je třeba využívat veškerých aktuálně dostupných prostředků.

Informantka 1: Osobně si myslím, že skypování je lepší kontakt, než žádný. Nebot co obvykle nechybí, je sluchový vjem. Senior slyši třeba „Mami!“, to je samozrejmě moc dưležité. Ted’ ale i tento zpưsob kontaktu chybí, nelíbi se mi to. Snad tato doba brzy skončí a príbuzníbudou moci po létě začít zase s návštěvami.

Videohovor $\mathrm{v}$ domově je téměř vždy vázán na osobní přítomnost aktivizačních pracovnic. Jedná se tedy z principu o neobvyklou formu setkávání.

Informantka 1: Jde o to, že já notebook musím připravit a dám ho seniorovi na výsuvný stoleček nad postel. Tam ho poté přidržuji, nebot by ho někteři senioři mohli srazit a navíc máme špatný wifi signál, který se ztrácí. Musím proto občas sit znovu prípojit a hovor opakovat. Vétšinou jsem tedy po dobu trvání videohovoru s nimi, a když neslyši nebo nerozumí, pomáhám se sdělením, opakuji... Pokud samozrejmè senior obsluhu zvládá bez problémů, domluvím se s ním a odcházím, aby mèl soukromí.

Vtipné situace nastávají, když třeba pomáháte při videohovoru paní, které je už přes devadesát, stojite vedle ní a ona povídá do notebooku: „Už mě občas ty sestry pěkně se...! A včera ta čůza přišla a vona...!" A ted"ta dcera na ní dělá: „P̌̌šššst, mami! Mami, stojí vedle Tebe! Neř́kej to!" A babička: "A jen at to slyši!" (smích). Videohovory tedy mohou být i pěkná legrace.

Informantka 2 reflektuje důvody, proč je ve skupině klientů s mentálním postižením situace kolem videohovorů poněkud odlišná.

Informantka 2: Videohovory neprobíhali $v$ naší skupině ani v první vlně a vlastně neprobíhají vỉbec ani nyní. Mladši klienti mají své mobilní telefony a s rodinami si telefonují. I když nemohou př́stroje ovládat sami, přijdou za námi a my jim rodinného př́slušníka vytočíme. Videohovory se přiliš nekonají i toho di̊vodu, že mnoho klientư rodinné příslušníky vůbec nemá, mají popř́padě jen opatrovniky.

\section{Úmrtí klientů}

Informantka 1 se mimo jiné zmínila i o svém dětství. Byla vychovávána prababičkou a v prostředí seniorů se pohybuje celý život - nyní i profesně. Osudy „jejích“ klientů se jí dle jejího vyjádření osobně dotýkají. Přibližzila, že senioři se jí často svěřují s velmi osobními záležitostmi. Důvod, proč si získala důvěru, vidí v tom, že má na seniory čas na rozdíl od „nevýchovného“ (zdravotnického) personálu. Svěřila se, že důsledkem osobnějšího vztahu s klienty o to hůře snáší, když umírají. Ve svých výpovědích opakovaně popisovala frustraci z úmrtí klientů během šíření nákazy v DSS. 
Informantka 1: V době covidové virózy jsme přišli o patnáct klientů během tři týdnů. Nevím, jestli se $v$ takovém prípadè dá mluvit o štěstí, ale v době nejvyšší smrtnosti klientů $v$ ústavu jsem také byla nemocná, a když jsem opèt nastoupila po prodělaném virovém onemocnění na pracovní pozici, už byla situace klidnější. Zemřeli během chvíle ženy a muži, kteří by bez onemocnění covid-19 ještě na tomto světe žili další spokojené roky. Zemřeli muži kolem 65 let, neměli jiné onemocnění, než kompenzovaný diabetes. Muž s diabetem, člověk plný optimismu, který během dvou dnů náhle „sešel“ a druhý den ráno se neprobudil.

$Z$ těch patnácti lidí zemřeli v nemocnicích pouze tř̀i. Ostatní zemřeli náhle, většinou během noci. Bez př́znaků, obvykle bez horeček. Zřejmě se virová nákaza přidružila $k$ další chorobě a klient se ráno neprobudil ze spánku.

Pro mě je traumatizující, že klienty vídáte dennè, berete je jako jakousi rodinu. Svěří se Vám, dají Vám di̊věru. A pokud odejde tolik lidí najednou, vzbudí se ve Vás silný pocit beznaděje. Nebot vidíte, že ta choroba dokáže usmrtit tak značné množství lidí tak rychlým zpưsobem.

Informantka 1 vysvětluje, že u tohoto onemocnění je pro ni nejtíživější právě ona nepředvídatelnost a náhlost úmrtí.

Informantka 1: Pokud většina seniorů „odcházi“ $z$ tohoto světa, vidite to týdny dopředu. Jde o jasné signály: změní se v obličeji výraz a tvar kostí, opouští ho energie a prestává jíst. U koronavirové infekce je vše náhlé. Nemáte čas si s nimi popovídat. Najednou jsou pryč, to je smutné.

Já se vlastně s umírajícími pacienty snažím obecně neloučit, nechcete jim jejich poslední chvíle... Takhle: já bych slzela, vím to o sobè. Proto se je i v těchto chvílích snažím povzbuzovat, mluvit vesele, probírat optimistické chvilky. Aby nemuseli při umírání myslet na něco zlého. Kdybych s nimi probírala nějaká smutná témata, budu tam u nich brečet a to bych jim rozhodně moc nepomohla. A když vidím, že umírají, snažím se za nimi chodit častěji, trávit s nimi ještě více chvil - i když na patře je další neuvěritelná spousta dalších klientù.

Ale u současných náhlých úmrtí vázaných na onemocnění tímto virem se necítím nejlépe a říkám si: „proč jsem to nepředjímala, mohla jsem za ním ještě zajít, povzbudit, něco hezkého mu ř́ct...".

Podle výpovědi informantky 2 mají snížené kognitivní schopnosti u klientů s mentálním postižením vliv na prožívání nebezpečí pandemie i na vnímání úmrtí nemocných.

Informantka 2: V první vlně jsme klientưm pořád v̌̌s vysvětlovali, ale reálně se covid v domově neobjevil, nebezpečí tedy pro nás všechny bylo daleko. Ve druhé vlně se infekce do domova zavlekla, zasáhla ve velké míre do osudi̊ a životů klientů, většina klientů si covidem prošla, včetně personálu. Najednou klientưm umírali nečekaně kamarádi, u kterých se rozhodně neočekávalo, že mohou odejít. Někteří si možná smrt svých kamarádư ani naplno neuvědomili: to je u klientů s mentálním postižením možná určitou výhodou, nebot často nepochopí souvislosti. Kamarád jim prostě odjel do nemocnice a už se nevrátil. Domnívám se, že některým se nespojují informace do uvědomèní té skutečnosti, že jim kamarád v nemocnici zemřel. V tomto jsou klienti s těžkým mentálním postižením určitým zpi̊sobem „splachovací, důsledky některých jevi̊ neřeší.

\section{Vakcinace jako symbol naděje}

Senioři v tomto domově prý mohou prožívat i jakousi frustraci z mediálního zpravodajství, které zásobuje uměle uzavřené prostředí DSS množstvím negativních informací. Informantka 1 zmínila velmi významný faktor, který v současné době ovlivňuje způsob prožívání pandemie u seniorů: nástup vakcinace.

Informantka 1: Někteří už automaticky přepínajízprávy v televizi, je toho na ně moc. Za posledních 14 
dní se jejich prožívání pandemie ale mění, nebot u nich proběhlo první kolo vakcinace. Optimisticky je to naladilo s vědomým tušením, že tato těžká životní epizoda končí. A já nemám to srdce jim ríci, že když dostanou druhou vakcínu, neznamená to, že budou moci jít za bránu domova sociálních služeb. V nich je nyní naděje, že dostanou druhou vakcínu a vše bude povolené... Ale ta situace tomu zatím neodpovídá. To mě trápí. Máme strach, co to s některými klienty udělá, až se dozvědí, že dostanou druhou vakcínu, ale brány se neotevřou a zavření potrvá.

Když jsem se informantky 2 ptal, jestli ona sama vidí v očkování naději, odpovídá spíše stř́źlivě a neurčitě:

Informantka 2: popravdě řečeno nevím. Také jsem se nechala očkovat. Spíše kvůli možnosti, která se objevila a kvưli klientům, se kterými pracuji. Ale jestli to k něčemu bude... Nevím, těžko říci. Ani jsem netušila, co se mnou vakcína udělá. První dávka mě nezabila, tak snad to bude dobrý (smích).

\section{Péče o duši}

Informantka 1 popsala velmi zásadní věc: jak je pro člověka podstatná činnost a kontakt. Starý člověk, velmi často upoutaný na lůžko bez schopnosti lokomoce, je odkázán na verbální či haptický kontakt druhých. Tělesný kontakt v podobě pohlazení, chytnutí za ruku od př́buzných apod. je tak $\mathrm{v}$ době protipandemických opatření zakázaným nebezpečím, což je dle informantek pro seniory frustrující.

Informantka 1: Pro mladší seniory je zatím výborná pohybová terapie. Udržuje se zde park, klienti hrabají listí, prořezávají stromy... S tím stráví mnoho času, obvykle celé dopoledne. To jim, myslím, hodně pomáhá v tom, aby úplně nepropadali depresím.

U seniorek v pokročilém věku toto nejde. Snažím se (když za nimi přijdu) je zorientovat, říci, co je $z a$ den. Nebot když celý den pouze ležite a poslední velký okamžik z celého dne je v pět hodin večerée, $v$ jednu hodinu $v$ noci Vás príijdou pouze prebalit a mezi tím až do rána nevidíte nikoho... To je strašně dlouhý čas.

Pro tyto seniorky je nejen dưležitý verbální kontakt, ale i haptický. Že si na Vás mohou sáhnout. To je strašně důležité. Pokud přijdete a pohladite je po ruce, ten dotek pro ně znamená velmi mnoho. I do esejů jsem psala, že pokud jsme pořádali videohovory po Skypu, senioři mluvili s př́buznými do obrazovky, ale já jsem je držela za ruku. Když by byly totiž povolené návštěevy, př́buzní přijdou, seniory drží za ruce, povídají si s nimi.

A právě ten tělesný kontakt jim $v$ době protipandemických opatření žalostně chybí.

\section{Postoj k protipandemickým opatřením}

Vyzval jsem informantku 1, aby zkusila co nejkonkrétněji vyjádřit svůj vztah k protipandemickým opatřením, která jsou v současné době předmětem mediálních kauz i sporů odborné veřejnosti. Informantka zformulovala svůj názor na základě prožitých zkušeností.

Informantka 1: Domnívám se, že názor některých lidí na situaci se zmiňovaným onemocnèním je limitován nedostatkem zkušeností s těžšími př́pady. Dvě kolegyně z personálu našeho domova sociálních služeb skončily v nemocnici díky dramatickému prüběhu onemocnění. Dle mého názoru je disciplinovanost na místě, to je můj názor. Lidé, kteři nemoc bagatelizují, by mohli zkusit vypomáhat na čtrnáct dní v nemocnicích, zlehčování mě totiž překvapuje. Samozřejmě: když jsem já zůstala sonemocnèním doma, zjistilo se, že jsem nakazila členy své rodiny. Ale manžel i dcera byli bezpríznakoví, zaplatbůh za to. Ale ne každému se takto poštěstí. A není automatické, že když byl jednou průběh bezpř́znakový, bude tomu tak opět při opětovné nákaze. Jsme takový rebelujicí 
národ: jestli je to tím, že jsme byli desítky let pod knutou?...A tak máme zapotřebí při př́padných omezeních vystrkovat růžky, to opravdu nevím. Ale dle mého bychom v tomto př́padè měli více myslet na ostatní.

Jestli je to tím, že spolu přestali žit generace, nestýkají se tolik a senioři jsou mladší generaci tak trochu fuk? Opravdu nevím. Ale případy jsou v mé práci viditelné. Ilustrující jsou příklady babiček a dědečkü, kteři mají návštěvy pouze ve „výplatní den“. A velmi řídké jsou případy, že by za seniory docházela vnoučata, což je v prípadě devadesátiletého seniora skutečně dospělý člověk. Pokud zř́dkakdy vnoučata dorazí, je evidentní, že jsou z návštěvy tak nervózní, že rychle pádí pryč. Osobně žiju s tchyní a generace $v$ našem soužití jsou propojené. Na své dceři vidím, že snad i díky tomu dennímu kontaktu se sedmdesátiletou babičkou jí nevadí za mnou chodit a se seniorkami se přirozeně baví. Což je jiná situace než u dítěte, které osobní zkušenost s pravidelným setkáváním s prarodičem-seniorem nemá a vidíbabičku jednou za dva měsíce na hodinu v ústavním zařizení...

\section{Pozitiva „covidové“ doby?}

S kolegou jsme na Teologické fakultě JU sesbírali 182 psaných esejí, ve kterých je možné zachytit postoj posluchačů $\mathrm{k}$ současné době ovlivněné pandemií nemoci covid-19. Sporadicky se objevovaly i autorské eseje, ve kterých studenti oboru pedagogika volného času vnímali v aktuální situaci rovněž jistou pozitivní výzvu.

Také informantky při nestrukturovaném rozhovoru odpovídaly na otázku, zda i na této těžké době spatřují prizmatem svých zkušeností a zážitků něco pozitivního. Byly samozřejmě ujištěny, že svou odpověd' nemusí za každou cenu konstruovat. Informantka 1 se dívá na aktuální situaci právě optikou své pomáhající profese.

Informantka 1: Lidem v produktivním věku, workoholikưm, kteři mají díky protipandemickým opatřením možnost objevit př́iemný společný čas se svými dětmi a rozumí si s nimi, může tato doba ukázat mnohé. Ale seniorùm, kteři tráví čas v ústavech, tato doba nic dobrého neprináší.

Někdo v této době snad vidí něco pozitivního, nevím. Situace u nás v domově je ale taková, že nemi̊žeme pozvat ani muziku, nemůžeme realizovat canisterapeutické akce... Objevuje se zoufalá ústavní monotónnost, která nedělá klientưm dobře.

Zưstává ve mnè malý stř́peček naděje, že léto už by mohlo být normální. Člověk musí doufat v něco lepšího. Jinak by měl tu depresi sám (smích). Takže když chodím k těm seniorkám, říkám jim: vydržte, určitě se to zlepší! A ony byly tím očkováním tak nadšené... Tak to nadření podporuji. Hlavně aby se situace nezhoršila. Takže ano, jsem optimista, v této práci musíte být. Jinak časem odcházíte do jiného zamèstnání.

Ani informantka 2 na základě svých zkušeností z DSS nespatřuje na této době nic přínosného. Když jsem jí vyzval, aby se vyjádřila k eventualitě, zda nákaza klientů domova může např. v dobrém ovlivnit rodinné vztahy, nebot si příbuzní klientů budou více vědomi podstatných hodnot, odpověděla informantka 2 spíše skepticky.

Informantka 2: Ani ne. Kdo za klienty predtím chodil, chodit opět bude, až se opatření rozvolní. Kdo chodil pouze jednou měsíčně, typicky patnáctého, bude zase chodit pouze patnáctého, až bude mít tu možnost.

Záleží většinou na tom, jakým zpưsobem si to rodina od začátku nastavila. Vztahy nezmění ani nákaza virem, který může být smrtelný. Pokud někdo za klientem předtím nechodil, nezaznamenala jsem, že by si rodina uvědomila to štěstí, že jejich rodinný př́islušník v domově nákazu covidem-19 přežil a začala si vážit společných okamžikư se svým př́buzným umístěným v domově. 


\section{Diskuze a závěr}

Př́spěvek staví na datech získaných od dvou informantek, které pracují v DSS. Tento domov se aktuálně potýká s problémem šiřrení nákazy. Uživatelé v sociálních službách i pracovníci domova jsou omezeni opatřeními, která mají za úkol zamezit či alespoň zpomalit šíření nákazy novým typem koronaviru SARS-CoV-2.

Jedná se o novou výzvu a novou situaci, jejiž dopady jsou aktuálně teprve v procesu šetření. Snahou tohoto príspěvku bylo za pomoci kvalitativních výzkumných nástrojů zachytit autentické výpovědi v konkrétním prostředí a pokusit se vyhnout účelovým interpretacím, ke kterým může téma svádět.

Informantky poskytly výchozí bod pro tento příspěvek: svůj př́běh popisující dynamický vývoj pandemie a způsob, kterým je domov ovlivňován, omezován a postihnut vlivem aktuální situace spojené s covidem-19.

Ve svých výpovědích zmínily, že obě vlny pandemické situace se od sebe kvalitativně liší. Jejich argumentace se opírá o fakt, že při druhé vlně se v domově rozšírila nákaza, která měla tvrdý dopad na životy klientů i na informantky samotné v osobním i pracovním životě. O změně ve vnímání epidemie a restriktivních opatřeních hovoří i anketní výzkum Nádvorníkové a Klimenta, kteří zmiňují, že jedním z faktorů pro vnímání situace jako vážné byl strach, který typicky zesílil při onemocnění někoho z personálu. ${ }^{25}$ Dopad na pracovní roli líći ve stejném duchu informantka 2 : onemocněním kolegyň a zavřením kantýny musela zastávat další pracovní aktivity (např. nákup cigaret pro klienty, zprostředkování komunikace s př́ibuznými potencionálně nemocných klientů a další) mimo konvence jejího pracovního zařazení.

Těžce informantky prožívají situaci náhlých úmrtí klientů zapříčiněných covidem-19. Také z psychologických výzkumů je známým faktem, že obzvláště tíživě prožívané jsou především ty události, které jsou jedincem vnímané jako neovlivnitelné a nepředvídatelné. ${ }^{26}$ Jankovský upozorňuje na stinnou stránku institucionálního modelu chladné, věcné, odosobněné profesionální péče. ${ }^{27}$ V kontrastu s tímto rizikem (který se dá považovat za určitou daň za profesionalizaci v pomáhajících profesích) vnímáme výpovědi informantky 2 a její účastný zájem o klienty.

Ve zprávě pracovní skupiny Rady vlády pro duševní zdraví, která mapovala dopady krize způsobené covidem-19 na duševní zdraví populace ČR, je konstatováno, že institucionalizovaná populace, včetně lidí s postižením, seniorů v institucích apod., byla restriktivními opatřeními tvrdě zasažena, a to zejména sociální izolací způsobenou omezením volného pohybu, resp. znemožněním návštěv. Zpráva konstatuje, že instituce nebyly připraveny a situace zvládaly intuitivně. ${ }^{28}$ Informantky zpřesňovaly sdělení o poznatky ze své praxe: protipandemická opatření prožíiají různé skupiny uživatelů $\mathrm{v}$ sociálních službách kvalitativně odlišně. Klienti s mentálním postižením prožívají situaci podle míry svých kognitivních schopností a míry ústavní deprivace. U uživatelů $\mathrm{v}$ sociálních službách je míra frustrace závislá na jejich individuálních potřebách (ilustrující je prŕípad klienta, který nemůže realizovat svůj „chodící rituál“ po snídani, nebot jsou brány domova zavřené). Informantky jmenovaly, že př́padnou frustraci pomáhá zmírnit např̀. fyzická činnost $\mathrm{v}$ prostředí areálu, aktivizační činnosti, haptický kontakt ( $\mathrm{v}$ př́ípadě nemohoucích seniorů

25 Srov. Pavel KLIMENT, Lenka NÁDVORNÍKOVÁ, Prvotní reflexe dopadu pandemie koronaviru na sociální služby v ČR, Fórum sociální práce $2 / 2020$, s. $20-28$.

26 Srov. Rita ATKINSON, Psychologie, Praha: Portál, 2003.

27 Srov. Jiří JANKOVSKÝ, Etika pro pomáhající profese, Praha: Triton, 2018, s. 155.

28 Srov. @ Dopady krize způsobené koronavirem SARS-CoV-2 a duševního zdraví populace ČR - zpráva pracovní skupiny Rady vlády pro duševní zdraví (on-line), dostupné na: https://www.mzcr.cz/wp-content/uploads/2020/01/Dopady-krize-zp\%C5\%AFsoben\%C3\%A9koronavirem-SARS-CoV-2-a-du\%C5\%A1evn\%C3\%ADho-zdrav\%C3\%AD-populace-\%C4\%8CR.pdf., citováno dne 20. 04.2021. 
upoutaných na lůžko), zprostředkovaný kontakt s př́ibuznými za pomoci videohovorů či navýšení medikace.

Zatímco ve zprávě pracovní skupiny Rady vlády pro duševní zdraví je coby příklad „dobré pra$\mathrm{xe}$ " formulováno doporučení zajistit alespoň online kontakt klientů s vnějším sociálním okolím, informantky líčily zkušenosti ze zvláště tíživé situace izolace klientů-seniorů, nebot videohovory nemohou zprostředkovat plnohodnotný kontakt. Informantky sdělovaly, že na kvalitu setkávání se seniory za pomocí videohovorů má reálně vliv nutná př́tomnost pracovnic domova, které pomáhají s technikou (ale zároveň mohou i rušit soukromí volajících) a omezené schopnosti seniorů přizpůsobit se tomuto typu distančního setkávání se svými př́ibuznými. Zřejmě i tyto faktory měly vliv na nižší četnost realizovaných videohovorů ve druhé vlně pandemie (trvající dosud). Informantky v rozhovorech líčily např. dramatiku situací: klienti-senioři se setkávají se svými rodinnými příslušníky prostřednictvím naaranžované techniky, kterou „obsluhuje“ sociální pracovnice. Ta musí být př́tomna po dobu videohovoru, aby asistovala a odstraňovala „technické pasti“. Zatímco senior mluví do obrazovky, na kterou často špatně vidí a kvůli nedoslýchavosti neslyší zvuk z reproduktoru, chybějící haptický kontakt mu „supluje“ sociální pracovnice, kterou senior drží po dobu videohovoru za ruku. Informantka $1 \mathrm{v}$ tomto duchu zmiňuje problém „haptické izolace" klientů-seniorů, pocit osamocenosti vznikající absencí tělesného kontaktu, kterou videohovor nevyřeší.

Informantky reflektovaly, že aktuálně probíhající očkování rizikových skupin mění u seniorů $\mathrm{v}$ tomto ústavu způsob proživání současné tíživé situace a dává naději. Zároveň informantka 1 zmínila, že vakcinace seniorů není jistým nástrojem ke zmírnění aktuálních opatření, což je zatím $\mathrm{v}$ tomto ústavu z pochopitelných důvodů (psychická pohoda klientů) tabuizováno.

V anketním šetření Nádvorníkové a Klimenta je glosováno, že někteří pracovníci v sociálních službách měli tendenci brát nastalou situaci na lehkou váhu, podceňovat ji a nechápali, proč je zapotř̌ebí přijmout karanténní opatření. ${ }^{29}$ Informantky v našem výzkumu se domnívají, že názor jedinců, kteří mají sklon bagatelizovat situaci a nutnost opatření, je limitován nedostatkem zkušeností $s$ těžšími př́pady onemocnění. Informantka 1 je toho názoru, že je disciplinovanost namístě: argumentuje těžkými př́ípady ze svého okolí i faktem, že se nakazila v sociálních službách a poté nákazu přenesla na členy své rodiny.

Informantky nespatřují (optikou svých zkušeností v pomáhající profesi) žádná výrazná pozitiva $\mathrm{v}$ situacích způsobených současnou pandemií. Argumentují zejména frustrací potřeb klientů na jejich pracovišti a strachem o své blízké.

Výpovědi od informantek měly působivý přesah do mezilidských vztahů, do kterých je pracovník v sociálních službách „profesně zapleten“. Zatímco v některých výzkumných sondách zaměřených na pedagogické prostředí je situace hodnocena i pozitivně (např. distanční výuka jako pozitivní výzva pro pedagogy i rodiče, možnost společně tráveného času apod. ${ }^{30}$ ), v prostředí DSS informantky hodnotí situaci jako zcela závažnou, tíživou. Př́činu lze spatřovat ve faktu, že nákaza klientů domova je pro zranitelnou skupinu potencionálním ohrožením života. Informantky se nedomnívají, že současná krize napomůže rodinným př́ślušníkům k reflektování „skutečných hodnot" a narušené vztahy (kterých jsou informantky svědky) se zharmonizují pod úlevným vydechnutím príbuzných, že jejich blízký ubytovaný v DSS přežil nákazu virem, který pro něj mohl být smrtelný.

29 Srov. Pavel KLIMENT, Lenka NÁDVORNÍKOVÁ, Prvotní reflexe dopadu pandemie koronaviru na sociální služby v ČR, Fórum sociální práce $2 / 2020$, s. $20-28$.

30 Srov. Roman ŠVA ǨICCEK, Jana STRAKOVÁ, Cyril BROM, David GREGER, Tereza HANNEMANN, Jiři LUKAVSKÝ, Mandatory home education during the COVID-19 lockdown in the Czech Republic: A rapid survey of 1st - 9th graders' parents, Frontiers in Education $5 / 2020$, s. $1-8$. 
Obecné doporučení pro praxi je možné nalézt v materiálech, které mapovaly dopady na duševní zdraví pracovníků $\mathrm{v}$ pomáhajících profesích. ${ }^{31} \mathrm{~V}$ našem příspěvku je možné díky výpovědím informantek rozklíčovat jemné nuance praxe v sociálních službách, které sebou vážná situace přinesla a přináší. Informantky reflektovaly i situace z podstaty velmi těžké (umírání klientů, snaha o povzbuzování těch, kteří pod současnou mimořádnou situací strádají apod.). Věříme, že ilustrace i těchto zkušeností z praxe může napomoci ke komplexnějšímu pochopení specifik a nároků profese, jejímž „nástrojem“ je lidský vztah a jednání konkrétních jednotlivců.

\section{Kontakt}

Mgr. Josef Nota, Ph.D.

Jihočeská univerzita v Českých Budějovicích

Teologická fakulta

Katedra pedagogiky

Kněžská 8, 37001 České Budějovice

jnota@tf.jcu.cz

31 Srov. Pavel KLIMENT, Lenka NÁDVORNÍKOVÁ, Prvotní reflexe dopadu pandemie koronaviru na sociální služby v ČR, Fórum sociální práce 2/2020, s. 20-28. 